\title{
Challenges of Rubber Smallholders in Increasing the Rubber Productivity in Batu Kurau, Perak
}

Sanssuria Ismail, Nur Amalina Ismail, Ismail Mohd Ali

To Link this Article: http://dx.doi.org/10.6007/IJARBSS/v11-i2/7929

DOI:10.6007/IJARBSS/v11-i2/7929

Received: 30 December 2020, Revised: 15 January 2021, Accepted: 30 January 2021

Published Online: 16 February 2021

In-Text Citation: (Ismail et al., 2021)

To Cite this Article: Ismail, S., Ismail, N. A., \& Ali, I. M. (2021). Challenges of Rubber Smallholders in Increasing the Rubber Productivity in Batu Kurau, Perak. International Journal of Academic Research in Business and Social Sciences, 11(2), 241-249.

Copyright: (c) 2021 The Author(s)

Published by Human Resource Management Academic Research Society (www.hrmars.com)

This article is published under the Creative Commons Attribution (CC BY 4.0) license. Anyone may reproduce, distribute, translate and create derivative works of this article (for both commercial and non-commercial purposes), subject to full attribution to the original publication and authors. The full terms of this license may be seen

at: http://creativecommons.org/licences/by/4.0/legalcode

Vol. 11, No. 2, 2021, Pg. 241 - 249

Full Terms \& Conditions of access and use can be found at http://hrmars.com/index.php/pages/detail/publication-ethics 


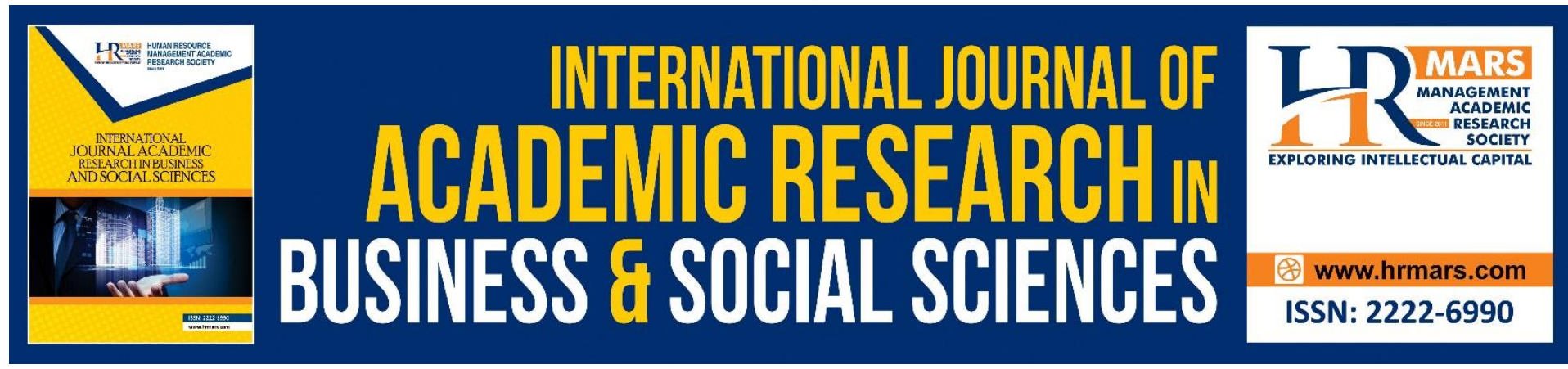

\title{
Challenges of Rubber Smallholders in Increasing the Rubber Productivity in Batu Kurau, Perak
}

\author{
Sanssuria Ismail ${ }^{1}$, Nur Amalina Ismail ${ }^{2}$, Ismail Mohd $\mathrm{Ali}^{3}$ \\ ${ }^{1,2}$ Faculty of Plantation and Agrotechnology, Universiti Teknologi MARA, Cawangan Melaka, \\ Kampus Jasin, ${ }^{3}$ Civil Engineering Deparment, Politeknik Sultan Idris Shah \\ Email: amalina1520@uitm.edu.my
}

\begin{abstract}
Malaysia once became the top-listing country in rubber production worldwide. However, in the couple last decades, the country rubber production is starting to drop significantly. Many reasons may be the cause of this problem. One of them is the reduction in the numbers of estate companies and smallholders. Almost $90 \%$ of the country's rubber production is owned by the local smallholders. Most of them are registered with the Rural Industry Smallholder Authority (RISDA). RISDA's officers are responsible for delivering useful knowledge and technologies to the smallholders. However, some factors may affect the rubber production of local smallholders that result in the reduction of production. The study aims to determine the most influential factor that are might becoming the factors in the difficulty of the rubber smallholders to increase rubber production. In this study, the factors involved are motivation, skill, technology, and climate. This study was conducted at Batu Kurau, Perak via a questionnaire method that involved 127 respondents by using the random sampling technique. The random sampling technique is beneficial in reducing bias. The data collected was run and tested for descriptive analysis and regression by using SPSS version 23 . Through regression, the result shows that skill is the most influencing factor that causes a decrease in rubber production in Batu Kurau, Perak. In a nutshell, this study is beneficial for reference by the RISDA officers and the smallholders to determine the proper solution needed for low rubber production issues based on the factors included in the study especially the skill factor. Keywords: RISDA, Natural Rubber (NR), Smallholder Motivation, WMDs, Skill, GAPs, Heavy Rainfall, Stimulants.
\end{abstract}

\section{Introduction}

The scientific name of the rubber tree is Hevea brasiliensis. In the early $20^{\text {th }}$ century, rubber had taken over the position of tin in the country. However, in 2019, the production of rubber was reported to decline in Malaysia, Thailand, and Indonesia. This involved the local smallholders, plantation, multinational and joint ventures with United States, Europe, and Japan which is about 7 percent is held by the plantation companies and about 90 percent is owned by the local smallholders. Almost more than half of the local smallholders in Malaysia are registered as members of the Rural Industrial Smallholder Development Authority (RISDA). Malaysia is one of the world producer and exporter of natural rubber (NR) which 
produce almost half of the world production. Even though Malaysia is on the top list of producing countries, the number of productions is decreased from the past three decades.

The study aims to determine the relationship of all independent variables such as the motivation of smallholder, skill, technology, and climate that contribute to the difficulty of the smallholders to increase the yield of rubber in Batu Kurau, Perak. Most of the rubber smallholders worked on their small-scale rubber cultivation. Due to this, the smallholder needs to have great motivators to keep them motivated in performing the activities ( Ghaffari, Mad Shah, Burgoyne, Nazri, \& Rezk Salleh, 2017). However, in the situation of the smallholders, the most influencing factors for them to become unmotivated are the level of age and health. Nowadays, age is playing an important role, especially when involved with the agricultural activities that required energy which accurately, when dealing with hands-on activities. Most of their body is incapable to continue working in extreme and time-consuming activities. This finding is supported by the statement that almost half of the farmers are at least 55 years old (Abdullah \& Sulaiman, 2013). The increase in age will bring about a negative effect on health. Most frequently of the problems are due to ergonomic issues. Some of these health issues incurred from ergonomic problems are known as Work-Related Musculoskeletal Disorders (WMDs). Suffered from WMDs thus reduce the performance in terms of work efficiency (Gadhavi \& Shukla, 2019).

Harvesting skill is the process of rubber tapping. Tapping too deep into the bark can also become the initial cause for the disease to be infected. The officers who are responsible for conveying and transferring the technology to the smallholders are from the RISDA's Extension Unit. Their general responsibilities are to improve the skills of the smallholders in terms of their skill, knowledge, and also their ability to understand and applied (Kahan, 2013). Education is important for the farmers as it can equip them with the required information and knowledge. Thus, enhance the productivity of the rubber tapper (Prince, Eric, \& Elfreda, 2014). In addition, they can easily react to any changes and diseases that threaten the tree. The rubber tree is risky in obtaining the disease during the growth through four ways which are via the stem, leaf, panel, and also root (Mazlan, Sulaiman, Wahab, \& Zulperi, 2019). Good agricultural practice (GAP) can be one of the solutions to the problem. In GAP that is produced by RISDA, there are 4 stages of GAPs which are GAP 1 is planting and maintenance, GAP 2 is manuring, Gap 3 is stimulation, and GAP 4 is harvesting (Amir, 2018). From the observation, the smallholders tend to neglect the following stages of GAPs especially manuring on mature trees.

Technology is proven in helping the agriculture sector in the country to booming. However, most of the technologies available in the market are high cost. Nevertheless, there is a high possibility that some of the smallholders are unaware of the free of charge latex coagulation that is provided by RISDA which is rubber latex coagulant and density enhancer, Hiska. Previously, people used formic acid or sulphuric acid to coagulate the tree as it is easy to access and cheap. Despite the accessibility, the use of the acid must be handle with care. This is due to its characteristic that is corrosive and flammable. From the test, it is sure that the Hiska can accelerate the time for the latex to coagulate, remove the odor of the rubber, and most importantly, safe to the human body. The product has been implemented by FELCRA around countries such as Pahang and Terengganu (Emmor, 2011). Apart from Hiska, rain guard is also a beneficial technology in the rubber tree industry that can be used to associate with the climate. The use of rain guard is good to be used mainly in the area with a high rainfall rate. It can increase the possibility of tapping the trees even during the rainy days 
as it can protect the tapping panel from becoming wet due to the rain. In addition, the area around Batu Kurau is in Taiping which is located near the Titiwangsa Ranges.

Rubber trees need a specific climate to grow. However, rubber tree maintenance is quite easy. Due to that, some may neglect the required maintenance on the tree. Rubber tree required the temperature between $20^{\circ} \mathrm{C}$ to $35^{\circ} \mathrm{C}$ with heavy rainfall. Hence, this tree is very suitable to be grown in Malaysia as the climate is similar to the requirements (Encyclopaedia Brittanica , 2020). Heavy rainfall may cause the tapping panel to wet. In addition, the tapping activities should be done early in the morning as the latex production is high during the time. If tapping on a watery tapping groove, the latex produced will be dripping off from the groove as water flow from rainfall. It will be a waste of energy, time, and the latex itself. Thus, reduce the day of tapping and income of the farmers. But, if rain after a few hours, the latex will not fully coagulate. Thus, rainfall can easily wash out the latex from the collection cup (Hazir, Abdul Kadir, \& Abd Karim, 2018). Hence, bring the loss to the smallholder.

\section{Materials and Methods}

The study was conducted at Batu Kurau which was situated in Taiping, Perak. The population in Batu Kurau is 23,924 persons. However, according to data collected from the Rural Industrial Smallholder Development Authority (RISDA) Taiping District Office, the total smallholders that are registered under them were only around 200 people. Due to that, Krejcie and Morgan Table were used to know the exact number of samples needed. According to the table, 127 persons out of 200 persons are required for the study. As the area of study was large, sampling technique which is a random sampling technique was used to ease the process of study and data collection. This technique is easy to apply and reduces timeconsuming. Furthermore, it can decrease the biased in the result. The primary data source was used to collect data from the respondents.

The questionnaire was developed before being distributed. However, in this study, Likert scale questions and demographic questions were used to develop the question for the survey. In the questionnaire, 5 point scale was used to measure the understanding of smallholders between the independent variables towards the dependent variable. The 5 point scale included 1 = "strongly disagree", 2 = "disagree", 3 = "satisfy", 4 = "agree", and 5 = "strongly agree". Firstly, it is crucial to define and determine the good objective for the study. The objective can be used to find good parameters that can be used to measure the study. Therefore, the parameters are used to design the questionnaire. The questionnaires were passed directly to the respondents without using the assistant of a middleman. The target respondents for the survey is 127 person.

Before the questionnaire is distributed to a large sample from the population, a pilot test must be run. In the pilot test, the designed questionnaire is distributed to the respondent. The data collected from the distributed questionnaire is analyzed by using the Statistical Package for Social Science (SPSS) version 23. A pilot test is also known as a reliability test. The reliability test is an important test to provide a high degree of certainty of a test. The result for the test is measure by using the coefficient alpha or Cronbach's alpha. The reliability coefficient ranges from 0 to 1 . Regression analysis is used in this study to describe the relationship between the independent variable and the dependent variable. 


\section{Results and Discussion}

Reliability analysis test

From the reliability test carried out by using SPSS, the result for Cronbach's Coefficient Alpha is 0.746 which is more than 0.7. Thus, the questionnaire that is used for the research is reliable to be used to analyze and portrayed the real situation for the research.

Descriptive analysis for demographic

Table 2 listed the demographic analysis for the respondent in Batu Kurau which are gender, age, race, and also the level of education. Gender was measure with 2 scales which are male and female. Meanwhile, age, race, and also education were measured by using 4 scales respectively. From the information in the table, it shows that the mean for gender is

Table 1. Cronbach's Alpha result

\begin{tabular}{ccc}
\hline $\begin{array}{c}\text { Cronbach's } \\
\text { Alpha }\end{array}$ & $\begin{array}{c}\text { Cronbach's Alpha Based on Standardized } \\
\text { Items }\end{array}$ & N of Items \\
\hline .746 & .706 & 18 \\
\hline
\end{tabular}

1.425 which means the number of male respondents was higher than females with a standard deviation of 0.496 . Most of the respondents' ages were in the range of 41 years old as the mean shown in the table is 2.881 with a standard deviation of 1.044. From the analysis, most of the respondents' race was coming from Malay with a mean of 1.157 and a standard deviation of 0.622. In addition, the mean and standard deviation for the level of education is 2.535 and 0.924 respectively. This allocated that most of the respondents were passed from secondary school.

Table 2. Demographic analysis

\begin{tabular}{lrrrrr}
\hline & \multicolumn{5}{c}{ Maximu } \\
& $\mathrm{N}$ & Minimum & $\mathrm{m}$ & Mean & Std. Deviation \\
\hline a1gender & 127 & 1.00 & 2.00 & 1.4252 & .49633 \\
a2age & 127 & 1.00 & 4.00 & 2.8110 & 1.04450 \\
a3race & 127 & 1.00 & 4.00 & 1.1575 & .62266 \\
a4education & 127 & 1.00 & 4.00 & 2.5354 & .92406 \\
Valid N (listwise) & 127 & & & & \\
\hline
\end{tabular}

Descriptive analysis for the independent variable

The highest mean for motivation is 4.401 with a standard deviation of 0.633 . The question is either they are still capable to determine the tapping depth on the bark after or during dawn. This shows that most of them were capable to do so. The lowest mean is 3.897 with a standard deviation of 1.045 which means that majority of the respondents were going to tap the rubber tree even they are having health problems such as back pain.

In skill, the highest mean which is 4.055 with a standard deviation of 0.716 . Meanwhile, the lowest mean is 2.897 with a standard deviation of 1.418 . This indicated that most of the respondents agree that they obtained the knowledge of harvesting from the RISDA officers. In addition, the respondents know little that the taping knife can be the medium for disease transmission.

The data in technology shows that the mean is between 3.0 to 4.0 which is fair to agree. The highest mean is 4.307 with a standard deviation of 0.868 and the lowest mean is 3.031. The highest mean indicated that the respondents agreed to the statement that 
technology implementation can increase the production of yields. On the other hand, the majority of the respondents not sure whether they know the function of MORTEX.

The last independent variable is climate. The result shows that the mean is constant at 4 or agree. The highest mean is 4.551 with a standard deviation of 0.6 portrayed the situation of the rainwater will make the tapping panel wet and cannot be tap. Meanwhile, the lowest mean is 4.409 with a standard deviation of 0.716 which is the overall climate condition making the yield lowered.

The table shows the descriptive analysis for management. The mean for the data is 3.00 which is fair with a standard deviation between 0.9 to 1.3. The highest mean is 3.543 with a standard deviation of 0.940 which means that most respondents are aware of the importance of maintenance to the trees. The same goes for the awareness of the respondents in reacting to the disease infestation on their trees which means of 3.039 and 1.329 standard deviation.

Table 3. Descriptive analysis for the independent and dependent variable

\begin{tabular}{lrrrrr}
\hline & $\mathrm{N}$ & Minimum & Maximum & Mean & Std. Deviation \\
\hline bi5motivation & 127 & 1.00 & 5.00 & 4.4016 & .63321 \\
bi6motivation & 127 & 1.00 & 5.00 & 4.3071 & .86842 \\
bi7motivation & 127 & 1.00 & 5.00 & 4.0157 & .97577 \\
bi8motivation & 127 & 1.00 & 5.00 & 3.8976 & 1.04528 \\
bii9skill & 127 & 2.00 & 5.00 & 4.0551 & .71611 \\
bii10skill & 127 & 2.00 & 5.00 & 3.8740 & .81642 \\
bii11skill & 127 & 1.00 & 5.00 & 3.3071 & 1.38880 \\
bii12skill & 127 & 1.00 & 5.00 & 2.8976 & 1.41889 \\
biii13tech & 127 & 1.00 & 5.00 & 3.0315 & 1.17471 \\
biii14tech & 127 & 1.00 & 5.00 & 3.3071 & 1.01974 \\
biii15tech & 127 & 1.00 & 5.00 & 4.3071 & .86842 \\
biii16tech & 127 & 1.00 & 5.00 & 4.2205 & .82533 \\
biv17climate & 127 & 2.00 & 5.00 & 4.4488 & .66319 \\
biv18climate & 127 & 2.00 & 5.00 & 4.5512 & .60038 \\
biv19climate & 127 & 2.00 & 5.00 & 4.4488 & .68671 \\
biv20climate & 127 & 1.00 & 5.00 & 4.4094 & .71663 \\
c21mgt & 127 & 1.00 & 5.00 & 3.5433 & .94075 \\
c21mgt & 127 & 1.00 & 5.00 & 3.0394 & 1.32977 \\
Valid N & 127 & & & & \\
(listwise) & & & & & \\
\hline
\end{tabular}

\section{Regression}

Table 4 shows the regression analysis R-square result that is used in the analysis. The dependent variable used in this analysis is the management of a rubber tree. Meanwhile, the independent variables used are motivation, skill, technology, and climate. R square is the variance that can be used to predict the independent variable. In this case, $47.5 \%$ of the variance in management can be predicted from variable motivation, skill, technology, and climate. 
Table 4. Regression analysis R-square

\begin{tabular}{lrrrr}
\hline Model & R & R Square & Adjusted R Square & $\begin{array}{c}\text { Std. Error of the } \\
\text { Estimate }\end{array}$ \\
\hline 1 & $.689^{a}$ & .475 & .458 & .74001
\end{tabular}

In Table 5, the $p$-value associated with $F$ value where $F$ is 27.580 is very small which is 0.000 and was lower than 0.05 . This indicated that there is a statistically significant difference between motivation, skill, technology, and climate which is at least one of them can be used to measure the decreasing of rubber productivity. This result also shows that the regression of decreasing in rubber productivity is statistically significant where the value of adjusted Rsquare is $45.8 \%$. This means that about $45.8 \%$ of the variance in rubber productivity decrease was indicated by the variables and other variables that are not used in this study can also contribute to the rubber productivity decrease.

Table 5. ANOVA ${ }^{a}$

\begin{tabular}{llrrrrr}
\hline \multicolumn{1}{l}{ Model } & \multicolumn{2}{c}{ Sum of } & & & & \\
\hline 1 & Squares & Df & Mean Square & \multicolumn{1}{c}{ S } & \multicolumn{1}{c}{ Sig. } \\
\hline & Regression & 60.412 & 4 & 15.103 & 27.580 & $.000^{\mathrm{b}}$ \\
& Residual & 66.809 & 122 & .548 & & \\
& Total & 127.220 & 126 & & & \\
\hline
\end{tabular}

Table 6 shows the data for the factor variables on rubber productivity. It shows that skill $(B=0.676, p<0.05)$ had effect on the rubber productivity. Meanwhile, the other variables of factor did not give significant impact which are motivation on rubber productivity $(B=$ $0.065, p>0.05)$, technology on rubber productivity $(B=0.036, p>0.05)$ and climate on rubber productivity $(B=0.100, p>0.05)$. This shows that only one factor out of four factors was significant in this study. Thus, indicated that skill is the most significant factor in rubber productivity.

Table 6. Coefficients ${ }^{\mathrm{a}}$

\begin{tabular}{|c|c|c|c|c|c|c|}
\hline & & \multicolumn{2}{|c|}{$\begin{array}{l}\text { Unstandardized } \\
\text { Coefficients }\end{array}$} & \multirow{2}{*}{$\begin{array}{c}\text { Standardized } \\
\text { Coefficients } \\
\text { Beta }\end{array}$} & \multirow[b]{2}{*}{$\mathrm{t}$} & \multirow[b]{2}{*}{ Sig. } \\
\hline \multicolumn{2}{|c|}{ Model } & B & Std. Error & & & \\
\hline \multirow[t]{5}{*}{1} & (Constant) & -.956 & .833 & & -1.148 & .253 \\
\hline & $\begin{array}{l}\text { MeanMotivat } \\
\text { ion }\end{array}$ & .129 & .134 & .065 & .963 & .337 \\
\hline & MeanSkill & .756 & .085 & .676 & 8.893 & .000 \\
\hline & MeanTech & .050 & .102 & .036 & .490 & .625 \\
\hline & MeanClimate & .191 & .131 & .100 & 1.456 & .148 \\
\hline
\end{tabular}




\section{Conclusion}

In conclusion, many factors can contribute to the decreasing in rubber yield among the smallholders. Some of the factors that can contribute to the problem are motivation, skill, technology, and climate. However, only skill shows the significant variable that can affect the productivity of rubber while the other not. This is due to the Beta and $p$-value of skill $(B=$ $0.676, p<0.05)$.

If the skill of the respondents is at a low level, it may affect the production of latex. This is because tapping must be done with care such as tapping not deep into the bark as it can damage the bark and knowing the right method to make the groove with the right degree so that the latex can flow smoothly. This means that improvisation in the skill of respondents will result in higher rubber yield.

\section{References}

Abdullah, A., \& Sulaiman, N. (2013). Factors That Influence the Interest of Youths in Agricultural Entrepreneurship. International Journal of Business and Social Science.

Alam, M. M., Siwar, C., Murad, M. W., Molla, R. I., \& Toriman, M. E. (2010). Socioeconomic Profile of Farmer in Malaysia: Study on Integrated Agricultural Development Area in North-West Selangor. Agricultural Economics and Rural Development, New Series.

Amir, M. (2018). Kajian Cadangan Amalan Pertanian Lestari Pada Sistem Amalan Pertanian Baik RISDA.

Centers for Disease Control and Prevention. (2020). Retrieved from United State Department of Health and Human Services:

https://www.cdc.gov/visionhealth/basics/ced/fastfacts.htm

Economic History Malaya. (2020). Retrieved from Early 20th Century Rubber Development: https://www.ehm.my/publications/articles/about-rubber

Emmor. (2011). Hiska coagulates latex rapidly to enhance rubber yields. Sabah: Borneo Post Online.

Encyclopaedia Brittanica. (2020). Retrieved from Malaysia-Climate: https:// www.brittanica.com /place/Malaysia /Plant-and-animal-life

Gadhavi, B., \& Shukla, Y. (2019). Prevalence of Work Related Musculoskeletal Disorders in Farmers of Gujarat. International Journal of Research and Review.

Ghaffari, S., Mad Shah, I., Burgoyne, J., Nazri, M., \& Rezk Salleh, J. (2017). The Influence of Motivation on Job Performance: A Case Study at Universiti Teknologi Malaysia.

Gohet, E., Lacote, R., Leconte, A., Chapuset, T., Rivano, F., \& Chambon, B. (2016). Improving Rubber Smallholdings Productivity and Resilience through Adoption of Good Agricultural Practices.

Henriques, M. (2019). BBC in association with Corteva Agriscience. Retrieved from The Ageing Crisis Threatening Farming: http://www.bbc.com/future/bespoke/follow-thefood/the-ageing-crisis-threatening-farming/

Kahan, D. (2013). The Role of The Farm Management Specialist in Extension. FOOD AND AGRICULTURE ORGANIZATION OF THE UNITED NATIONS.

Kumpulan Ladang-Ladang Perbadanan Kedah Sdn Bhd. (2020). Retrieved from Tapping Panel Shade: https://www.klpk.com.my/tapping-panel-shade/

Malaysian Rubber Export Promotion Council. (2019). Retrieved from Malaysian Rubber Production, Consumption and Trade in Rubber:

http://www.mrepc.com/industry/world_production.php 
Mazlan, S., Sulaiman, Z., Wahab, A., \& Zulperi, D. (2019). Major Disease of Rubber (Hevea brasiliensis) in Malaysia. Pertanika Journal of Scholarly Research Reviews.

Mohd Hazir, M. H., Abdul Kadir, R., \& Abd Karim, Y. (2018). Projections on future impact and vulnerability of climate change towards rubber areas in Peninsular Malaysia. IOP Conference Series: Earth and Environmental Science.

Prince, A. A., Eric, O. O., \& Elfreda, A. N. (2014). Effect of Education on The Agricultural Productivity of Farmers in The Offinso Municipality. International Journal of Development Research.

Putri, R. E. (2019). Protecting Harvests: Rubber Tapping Rainguard Phase One.

Rainforest Alliance. (2012, September 15). Retrieved from Species Profile Rubber Tree: https://www.rainforest-alliance.org/species/rubber-tree

Rajalakshmy, V., \& Jayaratnam, K. (2000). Root disease and non-microbial maladies. Natural Rubber: Agro-management and crop processing (Eds. P.J George and C. Kuruvilla Jacob).

Rosaraso, R. (2015). Using reliability measures in test validation. European Scientific Journal. Rubber Rain Guards. (2020). Retrieved from Rubber rain guard : ttp://rubberrainguards.com/introduction.php

Sae-Lima, P., Naktange, C., Yoochae, T., Nirapathpongpornc, K., Viboonjund, U., Kongsawadworakuld, P., \& Narangajavanaa, J. (2019). Unraveling vascular development-related genes in laticifer -containing tissue of rubber tree by highthroughput transcriptome sequencing. Current Plant Biology.

Shah, S. A. (2019). The Malaysian Reserve. Retrieved from Natural rubber production affected by improper practice: https://themalaysianreserve.com/2019/08/21/natural-rubberproduction-affected-by-improper-practice/

Sombatsawat, E., Luangwilai, T., Ong-artborirak, P., \& Siriwong, W. (2019). Musculoskeletal Disorders Among Rice Farmers in Phimai District, Nakhon Ratchasima, Province, Thailand. Journal of Health Research.

Zaw, Z. N., Sdoodee, S., \& Lacote, R. (2017). Performances of Low frequency Rubber Tapping System with Rainguard in High Rainfall Area in Myanmar. Australian Journal of Crop Science. 